Edward M. Gramlich is a member of the Board of Governors of the Federal Reserve System. When this article was written, he was a professor in and Dean of the School of Public Policy at the University of Michigan.

\section{Mending But Not Ending Social Security: The Individual Accounts Plan}

\author{
Edward M. Gramlich
}

for he U.S. Social Security System, first formed back in the 1930s, is a government-defined benefit pension program financed by worker payroll taxes. As workers pay in their payroll taxes, they accumulate benefit credits. At any point in time, one can make some economic and demographic assumptions, project forward tax inflows and benefit outflows, and determine the long-run actuarial soundness of the system, or really the long-term consistency of the present set of tax and benefit schedules. Every year such forecasts are made by the Social Security and M edicare Trusteesthree cabinet officers, the Commissioner of Social Security, and two outside members. Although earlier Social Security legislation mandated that quadrennial outside advisory councils be appointed to review these forecasts and to comment on relevant policy issues, the last such council to examine the retirement system was the famous Greenspan Commission in 1983. But a new advisory council was formed in 1994, and I was asked to chair it. It included three members from business, three from unions, and various others from the private pension industry, the self-employment sector, independent representatives, and so forth, making 13 members in all. We met monthly from mid-1994 to mid-1996, commissioned a number of special studies, appointed two technical panels that made reports, and in January 1997 issued our own report. In this paper I discuss this report and the policy proposal I put forward for dealing with Social Security.

\section{THE 1995 TRUSTEES' REPORT}

Our main point of departure was the 1995 Trustees' Report. As has been widely reported in the press, the intermediate assumptions of this report were that the combined assets of the Old-Age, Survivors, and Disability (OASDI) Trust Funds would go below the safety level (a year's worth of benefits) in 2030, and that the assets of the Medicare Hospital ization Insurance (HI) Trust Fund (a separate entity that we are not examining here) would go below the safety level in 2002-a far more urgent situation. But since the conventional wisdom up to that point had been that these trust funds should be actuarially sound for 75 years, the fact that the OASDI trust fund assets were projected to go below the safety level as soon as 2030 was alarming enough. With both trust funds, the underlying demographics of the country are such that projected benefits are rising rapidly compared to payroll tax inflows, so that when the fund assets first go below the safety levelsay in 2030 - the funds will be increasingly far out of actuarial balance after that date.

These numbers reflect two deeper pension savings issues for the United States. One involves actuarial bal ance. In a stable, defined-benefit Social Security System with pay-as-you-go (PAYG) financing, the underlying accounting identity can be written as follows:

$$
t=(B / W)(S / N)=r \times d,
$$

where $t$ is the OASDI tax rate on taxable wages, $B$ is the average value of Social Security benefits, $W$ is average taxable wages, $\mathrm{S}$ is the number of Social Security recipients, and $\mathrm{N}$ is the number of workers. The overall numerator, $(B \times S)$, is aggregate 
Social Security benefits, and the overall denominator, $(\mathrm{W} \times \mathrm{N})$, is aggregate taxable wages, with the overall right-hand side equaling the payroll tax rate because of the PAYG identity. This identity can also be written as the product of the aggregate replacement rate, $(r=B / W)$, and the dependency ratio, $(d=S / N)$.

The U nited States now has an aging population, with people living longer and not having enough babies to stabilize the population share of young people. This means that the dependency ratio, $d$, is steadily rising, from about 0.29 today to about 0.56 by the end of the 75-year fore cast period. According to the PAYG identity, if nothing is done to aggregate replacement rates, the payroll tax rate will need to rise steadily to pay for the existing definedbenefit Social Security plan.

The second issue involves the rate of return. A nother property of a PAYG system, first pointed out by Paul Samuelson, is that the equilibrium real rate of return on worker contributions equals the rate of growth of the economy's real wage base (real wages times number of workers). This real wage base is slated to grow about 1 percent in the Trustees' long-term forecasts, which means that discounted benefits will become smaller relative to discounted tax payments for each new cohort of young adults (using the overall real interest rate of 2.3 percent as the discount factor). Money's worth ratios, the ratio of discounted benefits to discounted taxes paid by employees and employers on behalf of employees, can be computed for past and future cohorts.

Taking into account the redistribution within Social Security, spousal benefit levels and the likely share of families receiving them, disability insurance levels and the likely share of families receiving them, and survivor benefit levels and the likely share of families receiving them, the weighted average money's worth ratio for people retiring now is about 1.0. This means that, for those who retire this year, Social Security is approximately as good a financial deal as government bonds, which generally should be an attractive proposition in light of the social protections that Social Security confers. But while the overall ratio cycles a bit because of past movements in real interest rates, over the long run the aggregate money's worth ratio falls to about 0.7 for younger workers, even before any policy changes in OASDI replacement or tax rates are made. If policy changes are made to bring the system into actuarial balance, these money's worth ratios will become lower yet.

The interaction between these two issues sets up a difficult problem in political economics. Taxes could be raised or replacement ratios cut to keep the system in long-term PAYG balance. But the mere act of doing either of these things worsens the money's worth ratios for younger cohorts and threatens the future popularity of the system. The question of how to bring the system into financial balance while preserving its political popularity was the central issue faced by our council.

\section{DEALING WITH THE SOCIAL SECURITY DILEMMA: THREE PROPOSALS}

The council had three different approaches for dealing with this double dilemma. Each approach takes advantage of the macroeconomic proposition that future returns on both stocks and bonds are likely to exceed the implicit PAYG return of the present OASDI system. Two of the approaches take advantage of the additional macroeconomic proposition that the best way to insure a healthy retirement system in the 21st century is to raise national saving now.

One approach, known as the Maintain Benefits plan, would make minimal changes in benefit schedules, tax rates, and hence underlying rates of national saving. The trust fund finances would be preserved, and the money's worth ratios for younger workers raised through a huge investment of Social Security funds in equities. There are a number of difficulties with such an approach, and in fact in the end those favoring the Maintain Benefits approach 
wanted only to "study" central fund equity investment, not actually to do it. From a macroeconomic point of view, this approach could also be criticized as involving only an asset swap with the private sector - not new saving or new wealth creation.

A second approach, called the Personal Security Accounts plan, would replace the present defined benefit system with large-scale defined contributions held outside the OASDI trust fund. These accounts would be privately owned and managed, and hence more risky. The OASDI benefit schedule would revert to a poverty-line flat benefit, again increasing the risk that individuals who did not invest well would not receive many retirement benefits. Since the present-day payroll tax would be largely diverted to the personal accounts, a huge amount of transition financing would be required for such a plan.

I personally do not favor either approach and have tried to come up with an intermediate approach that preserves the important social protections of the present Social Security System, does this in a financially prudent way without relying on OASDI equity investment, and still adds what I consider to be badly needed new savings for retirement. My Individual Accounts (IA) plan does all three.

\section{COMPONENTS OF THE INDIVIDUAL ACCOUNTS PLAN}

The first component of the IA plan is what might be called "kind and gentle" benefit cuts. Most of the cuts would be felt by high-wage workers, while disabled and lowwage workers would be largely protected from cuts. The IA plan would involve some technical change; for example, all state and local new hires would be included in Social Security, and Social Security benefits would be subject to consistent income tax treatment. These changes are al so part of the council's other plans and go some way toward eliminating Social Security's actuarial deficit.

Then, beginning in the 21st century, the changes would be supplemented with two other measures. There would be a slight increase in the normal retirement age for all workers. There would also be a slight change in the benefit formula to reduce the growth of Social Security benefits for high-wage workers. Both of these changes would be phased in very gradually to avoid actual benefit cuts for present retirees and "notches" in the benefit schedule (instances when younger workers with the same earnings records get lower real benefits than older workers). The result of all changes would be a modest reduction in the overall OASDI replacement rate of Equation 1 to leave OASDI payroll tax rates stable into the future. In the context of the rising number of retirees, the share of the nation's output devoted to Social Security spending would be approximately the same as at present, eliminating this part of the impending explosion in future entitlement spending. Of the three plans suggested by our council, my plan is clearly the best for achieving shortterm and long-term balance in the federal budget.

These benefit cuts alone would mean that high-wage workers would not experience rising real benefits as their real wages grew, so I would supplement these changes with another measure to raise overall retirement (and national) savings. Workers would be required to contribute an extra 1.6 percent of their pay to individually owned accounts, which would be centrally managed. The workers would be able to allocate their funds among five to 10 broad mutual funds covering stocks and bonds. At the same time, central management of the funds would cut down the risk that they would be invested unwisely. It would al so cut administrative costs and would mean that Wall Street firms would not find these individual accounts a financial bonanza. The funds would be converted to real annuities upon the employee's retirement to protect against inflation and the chance that retirees would overspend in their early retirement years.

\section{CONCLUSION}

These changes, taken together, would mean that all wage classes of workers, of all ages, would receive approximately the level 
of benefits that is currently in place. The difference between this outcome and present law is that, under this IA plan, the benefits would be affordable; under present law, they are not. The changes would eliminate

Social Security's long-term financial deficit while preserving the important retirement safety net provided by Social Security. They would significantly raise the return on invested contributions for younger workers. They would reduce the growth of overall entitlement spending and improve the federal budget outlook, even in the near term. And the changes would move beyond the present PAYG financing scheme by building up the nation's capital stock in advance of the baby boom retirement crunch. 